\title{
Personalia
}

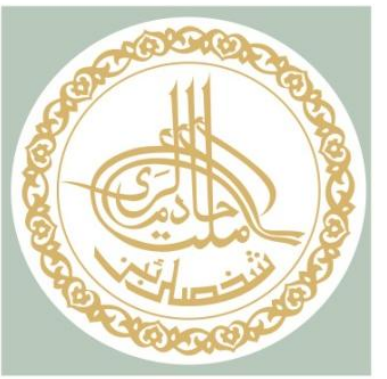

\section{NADIR DEVLET (1944 - 2021): IN MEMORY OF THE SCIENTIST, TEACHER, AND FRIEND}

\author{
İsmail Türkoğlu, \\ Mimar Sinan Fine Arts University, \\ Findıkl1, Istanbul, 34427, Turkey, \\ turkogluismail@yahoo.de.
}

DEVLET NADIR (1944 2021) was a historian, Ph.D. (1985), and Professor (1990). In 19631967 , he worked for the Islamic Encyclopedia Institution and from 1967 to 1971 , he was a researcher at the Institute of Turkish Culture in Ankara, Turkey. In 1972-1984, Davlet Nadir worked for the radio

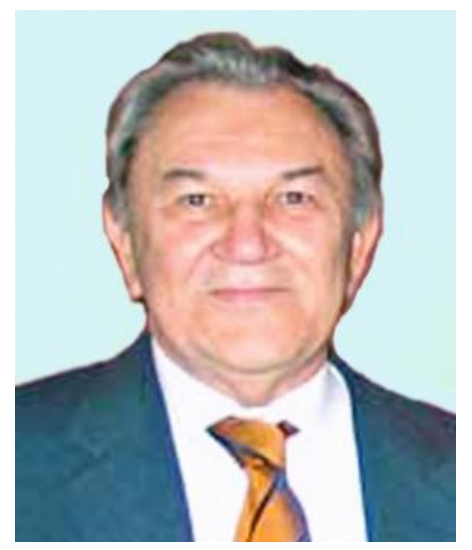

ДӘУЛӘТ НАДИР (1944 2021) - тарихчы, тарих фәннәре докторы (1985), профессор (1990). 1963- 1967 елларда Төркиянең Әнкара шәһәрендә Ислам энциклопедиясе, 1967-1971 елларда Төрек мәдәнияте фәннитикшерену институты хезмәткәре. 1972-1984 елларда Мюн-
ДАУЛЕТ НАДИР (19442021) - историк, доктор исторических наук (1985), профессор (1990). В 1963-1967 гг. сотрудник «Исламской энциклопедии», в 1967-1971 гг. сотрудник НИИ тюркской культуры в Анкаре (Турция). В 1972-1984 гг. работает на радиостанции «Свобода» ${ }^{1}$ в

\footnotetext{
${ }^{1}$ Татаро-башкирская служба Радио Свобода (Azatliq Radiosi) с 5 декабря 2017 г. внесено в Реестр иностранных средств массовой информации, выполняющих функции иностранного агента Министерства юстиции РФ [Реестр иностранных средств массовой информации, выполняющих функции иностранного агента: Министерство юстиции Российской Федерации (minjust.gov.ru)].
} 
station "Liberty" in Munich, Germany. Simultaneously, in 1970 1980, he was an editor-in-chief and one of the editors of the Turkish journal "Kazan". From 1984, he was a lecturer, and later, a professor of Marmara University in Istanbul. His works were devoted to the history of the Turkic peoples and international relations. His numerous articles and 20 monographs were published in different languages, including four books in the Tatar language. хенда (ГФР) «Азатлык» радиостанциясендә эшли. Бер үк вакытта 1970-1980 елларда Төркиядә нәшер ителгән «Казан» журналының баш мөхәррире һәм мөхәррире. 1984 елдан Истанбулда Мәрмәрә университетында укыта, профессор. Хезмәтләре төрки халыклар тарихына һәм халыкара мөнәсәбәтләргә карый. Төрле телләрдә күпсанлы мәкаләләре, 20 монографиясе нәшер ителгән, шулар арасында татар телендә 4 монографиясе бар
Мюнхене (ФРГ). Одновременно в 1970-1980 гг. - главный редактор и редактор издававшегося в Турции журнала «Казан». С 1984 года преподаватель, затем профессор Мармарского университета в Стамбуле (Турция). Труды по истории тюркских народов и международным отношениям. На разных языках изданы многочисленные статьи, 20 монографий, среди которых 4 монографии на татарском языке.
Nadir Devlet was born on July 15, 1944, in the city of Mukden, which is now the capital of the Liaoning Province of the People's Republic of China and is called Shenyang. The future scientist was born into the Tatar family of Ibrahim and Rukia Devletkildieevs. His great-grandfather, Muhammedjan Efendi, was a merchant and an entrepreneur. In the city of Petropavlovsk (now in Kazakhstan), the Devletkildeev family owned a creamery, a soap factory, as well as mills and kerosene warehouses. The mosque, built by the family in this city in 1868 , is still open for worship. Before the revolution of 1917, their clan, consisting of 38 families, whose representatives were Tatar princes and descendants of the Golden Horde khans, lived in tsarist Russia. After the revolution, having lost their property, their titles and social status, they were forced to settle in various parts of the Union of Soviet Socialist Republics. The tragic story of the Devletkildeevs' wanderings during the Stalin era was reconstructed in the six-part documentary film "The Story of My Family" (directed by Marina Razbezhkina).

Rukiye-khanum was a daughter of merchant Sabirzhan Mukhammedish(in) $(1873-1947)^{1}$. The grandfather of the future scientist was engaged in trade along the Trans-Siberian Railway, which was under construction. Sabirzhan Abzy sold raw materials from Siberia and household items, bought in the European part of Russia in various cities of Siberia and at the stations of the Trans-Siberian Railway.

Nadir Devlet's mother Rukiye-khanym (19081989) was born in 1908 in the village of Utyamyshevo (Utemesh) in the Tetyushi uezd (district) of the Kazan province (now it is the Apastovo district of the Republic of Tatarstan).

\footnotetext{
${ }^{1}$ See her biography in the book: "Rokiye Deületkildi: The Bitter Life-Story of a Tatar Woman" [Рокыя Дәүләт-Килде: Бер татар хатының ачы язмышы].
}

From an early age, she was forced to travel because of her father's commercial activities. The family moved to the Siberian city of Irkutsk in 1911, and in 1916, they moved from there to Khabarovsk. For two years, she stayed in the city of Blagoveshchensk, and in 1918, the family returned back to Khabarovsk. Owing to her father's good income, Rukiye could study at the Russian gymnasium in Ussuriysk, from which she graduated in 1919. Due to the social upheaval in Russia in 1925 , the family was forced to move to China and settle in Harbin, later, in 1927, they moved to Japan to live in Tokyo. The family settled in the cities where the families of Tatar emigrants lived after they had fled Russia before and after the revolution of 1917. Rukiye-khanum attended English and secretarial courses in Tokyo for a while, and then, until 1935, taught at an Islamic school, where the children of Tatar emigrants, living in the city, studied. The famous Tatar writer Gayaz Iskhaki, who lived in exile in Berlin and Warsaw, and published the journal called "Yana Milli Yul" ("The New National Way"), needed constant financial support to conduct his activities. Since the number of Turkic-Tatar Muhajirs in Europe was small, they could not provide him with decent financial assistance. From 1933 to 1938, in search for funding, Mr. Iskhaki went to the Far East. When he got to Tokyo, by the will of fate, he met Rukiye-khanum. Brought up on Iskhaki's books and being impressed by the writer's speeches, Nadir's mother joined the colleagues fighting for the liberation of Idel-Ural.

The leaders of the Tatar Islamic community in Tokyo consisted of wealthy families. Muhammad Kurbangali(ev) and(G)Abdurreshid Ibrahim(ov) did not allow Gayaz Ishaq to establish control over their activities. In fact, from 1905, the relationship between Gayaz Ishaki and Abdurreshid Ibrahim was strained. Gayaz Ishaki was a socialist in his youth and led a secular lifestyle, so it was difficult 
for him to find a common language with the older generation who strictly adhered to Islamic traditions. This led to serious disagreements. After that, Gayaz Iskhaki decided to organize the Far Eastern Congress of the Turk-Tatars in Mukden (Manchuria) on February 4-14, 1935. He found his supporter in the person of Rukiye khanum's father. Soon Nadir Devlet's mother, thanks to her knowledge of foreign languages, became an indispensable assistant to Gayaz Iskhaki. As a result of the Congress, the newspaper "Milli Bayrak" ("The National Flag") was published in this city on November 1, 1935, and Gayaz Iskhaki returned back to Europe. In her letters to Gayaz Iskhaki, Rukiye-khanum begged him to take her to Europe, but he ignored her requests, believing that she should sacrifice herself (kurban) for the nation (millet). Subsequent events indicate that Rukiye-khanum sacrificed herself in the name of the nation. The readership of "Milli Bayrak" numbered 300-400 subscribers. The hand-written paper and the newspaper were replicated with the help of a typographic stone. The entire burden of publishing the newspaper fell on the shoulders of Rukiye-khanum. On 17 October 1943, she married Ibrahim Devlet-Kildi, who was the editor-in-chief of the "Milli Bayrak" newspaper. On July 15, 1944, their first child, named Nadir, was born. On August 10, 1945, Soviet troops entered Manchuria. The office of the "Mili Bayrak" newspaper was one of the first to be sealed. Nadir's parents were arrested, and the pregnant Rukiye-khanum and her husband were soon taken to Chita. Sabirzhan-efendi was left alone with his one-year-old grandson. During interrogations and tortures, the couple was forced to admit the charges against them. A year after their arrest, after a ten-minute trial, they were sentenced under Article 58 (paragraphs 2. and 11) of the Criminal Code of the RSFSR to imprisonment for a term of ten years to be served in a labor camp (GULAG) with confiscation of property. On April 22, 1946, Rukiye-khanum gave birth to her daughter Farida in prison. Together with her daughter, she was sent from Chita to a labor camp in Karaganda, one of the major mining cities in Kazakhstan. When the girl was three and a half years old, she was taken from her mother and placed in a state orphanage for the children of enemies of the people. Owing to ideological propaganda, Farida was brought up in hatred of parents from a young age. The harsh working conditions in the brick factory and stone quarry, which were too hard even men, severely undermined the health of Rukiyekhanim. The death of Stalin did not lead to changes in the conditions of those who were in the camp, and Nadir Devlet's mother began to fade away.

In February 1955, due to progressive chronic diseases and the inability to work in the conditions of the Karaganda camp, she was transferred to a labor camp in Mordovia, where she began working in a workshop for sewing military clothing. A year later, on November 10, 1955, at the end of her sentence, she was sent to the Novosibirsk prison, then, she was allowed to settle with her husband in the village of Vdovino in the north of the Novosibirsk region, where he was exiled. The state poultry farm was located there. After a long separation, the couple finally reunited. In October 1956, they managed to return their daughter, who had spent 7 years in an orphanage. The living conditions there were difficult. Rukiye-khanym had spent 10 years in a labor camp and 6 years in exile in the Novosibirsk region. In 1961, they got a relief, the family was allowed to return to her husband's homeland in Petropavlovsk (Kyzylyar). The former "enemies of the people" found it difficult to find a job. After a long ordeal, Rukiye-khanym managed to find an occupation in her field: finally in 1962, she began teaching English. However, troubles continued to haunt the family. On April 21, 1967, the head of the family, Ibrahim Bey, died of heart failure. Rukiye-khanim taught until 1976, as the tiny pension she received from 1972 was not enough to live on. She was grieving over the separation from her daughter, who worked as an engineer at the military Optical and Mechanical Plant (KOMZ) in Kazan. After a long correspondence, she managed to get permission to move to Kazan only on September 30, 1982. She and her daughter lived in different communal apartments, the authorities refused to register her on the same premises with her daughter. Years later, thanks to the patronage of friends in Kazan, Prof. Nadir Devlet improved the living conditions of his mother, she received a oneroom apartment.

The meeting of mother and son took place in July 1977 in Munich. Nadir Bey had already started a family and become a father. Giray was four years old when he met his grandmother. The second meeting of mother and son occurred in $\mathrm{Mu}-$ nich in 1983. Rukiye-khanim was able to hug her second grandson, named Yulai. This was Rukiye's last meeting with her son and his family. Her life of adventure and torment ended in Kazan in 1989, when she was 81 years old. Gayaz Iskhaki, indeed, sacrificed her for the Tatar people.

Nadir Devlet's father - Ibrahim Bey was born on February 27, 1901 in the city of Petropavlovsk 
(Kyzylyar). There were 11 children in the family. Ibrahim Bey received his primary education in a madrasah built by his grandfather. Later, he continued his education at the Russian secondary school, which he left in 1918. Fleeing from the revolutionary fire that was burning in Russia, Ibrahim Bey went to Vladivostok, located on the coast of the Sea of Japan, in search of salvation. Here he entered the radio telegraph courses. Although Ibrahim Bey was enlisted as a sailor in the army of Admiral Kolchak, who fought against the Reds, he soon found himself forcibly enlisted as a lieutenant in the army of Baron Roman Ungern von Sternberg, who was in the ranks of the Whites. After a while, at the invitation of his compatriots, he went to spend a vacation in Harbin. Ibrahim Bey had been dragged into the war against his will, when the Red Army entered the region. For the fact that Ibrahim Bey had fallen asleep while on duty, Baron Roman Ungern von Sternberg sentenced him to death. Nadir's father survived, thanks to the help of a Tatar officer who provided a shelter for him in his family house in Harbin.

In 1920, he entered the Ukrainian Lyceum in this city, and after successfully graduating from it in 1922, he went to Tokyo with the idea of taking up trade. But because of the great earthquake that occurred in 1923, he could not stay there for long. He survived the earthquake, left Tokyo in 1925, and went to Mukden to try his luck elsewhere. Here, he married Razie-khanum and had two daughters in this marriage. At this time, the Mukden Congress (Kurultai), headed by Gayaz Iskhaki, whom we mentioned above, was held, and Ibrahim Bey joined as a delegate. During this Kurultai, he met Rukiye-khanum, and together they began their work in the newspaper "Milli Bayrak", which was published by the decision of the Kurultai. Ibrahim Bey was the leading author in the paper. Meanwhile, in 1937, he divorced his wife, and six years later, in 1943, he married Rukiye-khanum.

After his arrest, he was sent from Chita to Moscow's famous Lefortovo prison for further investigation. Soon, after a short trial, he was sentenced under Article 58 (paragraphs 10 and 11) of the Criminal Code of the RSFSR to a ten-year imprisonment in a labor camp (GULAG). A decision was made to confiscate his property, and he was sent to a camp in the city of Uglich (the Yaroslavl region), north of Moscow. Due to the harsh working conditions, he soon fell ill and spent six months in the camp hospital. After his recovery, he was transferred to Camp No. 11 in Mordovia. He felled trees in the forest at thirty degrees of frost Celsius.
At the end of his sentence, on April 20, 1955, he was exiled to the Novosibirsk region. On the state farm of Vdovino, he worked as a herder, a laborer, and worked in the fields. When his family returned to his hometown, Ibrahim Bey worked in a warehouse. The family received their first home in 1964, but the joy was short-lived. His life was short. It was ordained from above that the father was not to meet his son.

The fate of Nadir's grandfather was also tragic. $\mathrm{He}$ died of tetanus due to a rusty nail that damaged his eye. No one knows who took care of little Nadir for six months.

Foster parents played a huge role in the life of Nadir Devlet and his development as a scientist. When fate decided to join the lives of the orphaned boy and Akhtem Bey and Ainirjamal- khanim, the couple was planning to emigrate from China to Turkey. Thanks to the help of a Jewish merchant, they first took the child of the famous parents from Mukden to Beijing, where they adopted him. Later, the family went to Shanghai. After the end of the Second World War, from 1949, power in China was in the hands of the Communists. A stepsister, named Rashida, appeared in the life of Nadir. Thanks to the help of her friends working at the Turkish embassy, she received a Turkish visa. On January 18, 1949, the family left Shanghai for Istanbul. After a seventy-day difficult ship cruise, they arrived in Istanbul on March 31, 1949. In Turkey, Nadir's foster parents changed their last name and took the name of Devlet, so that in the future his native parents could find the child. After spending the night in a hotel in Sirkeji, thanks to Gayaz Ishaki, they settled in an apartment in the Chershembe quarter of the Fatih district. The family was in a difficult economic situation until $\mathrm{Na}$ dir's stepsister managed to get a job, thanks to the help of Reshid Hamdullah Suphi Tanriöver, as a secretary in an oil company. The family settled in the basement of a residential building in the Shishli district. On May 19, 1951, Nadir entered the local primary school, which he left in 1956. The wealthy industrialist Ahmed Veli Menger (a native of Oly Menger village near Kazan), who knew the boy's parents closely during their work in the editorial office of Milli Bayrak, actively participated in the fate of the boy. He was joined by Kemal Lukman, an ethnic Tatar who was the first oil engineer in Turkey. Owing to their financial help Nadir Devlet continued his studies at the secondary department of the German private lyceum (Özel Alman Lisesi). It was during this period that Nadir learned that he was being raised by foster parents, which 
depressed him for a short time. Nadir Devlet could not complete his studies at the higher department of this educational institution, because Ahmet Veli Menger stopped paying for the boy's education after he failed to get him adopted. Kemal Lokman followed Ahmet Veli Menger's suit, as he was the richest Tatar in Turkey. Because of this, in 1962 Nadir Devlet had to go to the evening school (Vefa Akşam Lisesi) (Vefa Evening Secondary School). He combined his studies with work. Thanks to the help of Tatar emigrants, Nadir Devlet managed to get in touch with his own mother and sister Farida.

In 1967-1971, Nadir Devlet studied at the History Department of the Faculty of Literature in Istanbul University. In 1969, he married Dilek Orakoğlu, by whom he had two sons: Giray and Yulay. The starting point of his career biography began in 1951. He had various jobs. In 1963, the father of his school classmate, Professor Rashid Rahmeti Arat, helped Nadir, who had not come of age yet, to get a job of a proofreader in the "Islamic Encyclopedia" ("Islâm Ansiklopedisi"), published by the Ministry of Education. Together with his friends, Nadir Devlet started publishing the "Tukay Bulletin" (Tukay Bülteni). In 1967, he was offered a job by the Research Institute of Turkic Culture (Türk Kültürü Araştırma Enstitüsü), with its headquarters in Ankara. Nadir Devlet worked as a dictionary commissioner in the Istanbul Office in 1967-1972. At that time, the Institute was headed by his compatriot Professor Ahmet Temir. During those years, Nadir Devlet headed the Society of Culture and Assistance to the Kazan Turks. Together with his friends, he published the magazine "Kazan".

Thanks to the patronage of his friend Ferit Agi, Nadir Devlet worked in the Tatar-Bashkir editorial office of Radio Azatlyk, created by the United States after World War II in Munich for an ethnic audience living in the Union of Soviet Socialist Republics (RFE/RL Inc. - Radio Free Europe / Radio Liberty Inc.). Thanks to this work, in 1972, Nadir Devlet and his family moved to Munich. In 1972- 1975, he was a radio program host, in this way he improved his command of German, English, and Tatar, and gained access to various resources. It was during this period that Nadir Devlet mastered the Tatar literary language. In April 1975, he was forced to return to Turkey to do his military service in Bornova in the Izmir province, in the $58^{\text {th }}$ Training Division, $57^{\text {th }}$ Artillery Training Brigade. After being discharged from the army, he worked at the Ahmet Veli Menger Holding in Istanbul for some time. But, seeing no future in this position, he returned to Munich again to do his radio work. In 1976, under the guidance of Professor
Ibrahim Kafesoglu, he began working on his doctoral dissertation on the topic: "History of the National Struggle of the Russian Turks (1905- 1917)" ("Rusya Türkleri'nin Milli Mücadele Tarihi (19051917)", which he presented in 1982. Nadir Devlet began to apply to various universities in order to devote himself entirely to science and teaching.

At the invitation of the Dean of the Science and Literature Faculty of Marmara University, Professor Hakki Yildiz, Nadir Bey returned to Istanbul in the fall of 1984 and began teaching in the History Department. After returning to his homeland, he continued to work on the radio: until 2020, he led the weekly program "News of Turkey" using the pseudonym Akhtem Ibrahimov. After the collapse of the Soviet Union, Nadir Devlet's position in society became stronger than ever, as politicians treated him, who had known this world, with great respect. President Turgut Ozal and Prime Minister Mesut Yilmaz asked him to submit proposals concerning the Turkic-speaking peoples living in the Soviet Union. His series of articles were published in various journals. His fundamental work "The Modern Turks" ("Çağdaş Türkiler") has not lost its relevance to this day.

His academic teaching career also gained momentum ${ }^{2}$ : in 1986, he became an associate professor, and in 1992, a professor. From June 1989 to June 1990, he worked as a visiting researcher at the Center for Central Asian Studies at Columbia University, where he received an annual fellowship awarded by the American Council of Learned Societies and the Joint Program for the Development of Soviet Studies of the Social Science Research Council. Nadir Devlet worked as a visiting professor for the fall semester in the Department of History at the University of Wisconsin in the United States (August 1996January 1997). Here he taught the course "Invasions and Empires: Central Asia from Genghis Khan to Stalin, the Revolution in Central Asia and reform in Islam" " "Işgaller ve Imparatorluklar: Cengiz Han'dan Stalin'e Orta Asya ve Islâm ve Orta Asya'da Ihtilal ve Reform"). Till 1991, Nadir Devlet was the Deputy Director of the Center for Research and Practical Studies of Turkey, founded in 1986 at the University of Marmara. Thanks to the policy of publicity pursued by the President of the USSR Mikhail Gorbachev, the scientist managed to come to the scientific forum in Kazan in 1990. During this visit, he met his sister Farida, whom he knew only by correspondence. They met at the train station after forty-five years of separation. Nadir Devlet improved her fi-

\footnotetext{
${ }^{2}$ See: Devlet G. Beril [Devlet G. Beril]
} 
nancial situation in Russia, regularly providing her with financial assistance until her death.

Owing to the joint efforts of Professor Orhan Oğuz, the Rector of the University of Marmara, Professor Hakk1 Dursun Y1ld1z, the Dean of the Faculty of Science and Literature, Professor İnci Enginün, and Professor Nadir Devlet, on January 24, 1991, the Turkish Parliament adopted a law on the establishment of the Research Institute of Turkic Studies (Türkiyat Araştırma Enstitüsü) at the University of Marmara. In 1991- 1997, Nadir Devlet held the position of the Deputy Director at this Institute. Simultaneously, he taught at the History Department of the Faculty of Science and Literature. In 1997, after the retirement of Professor İnci Enginün, Dr. Nadir Devlet became director of the Institute. Under his leadership, a number of major international scientific events were organized: "Symposium on the Study of Turkism and Turkey in the World" (October 18-20, 1986); "The $5^{\text {th }}$ International Congress on the Social and Economic History of Turkey" (August 21-25, 1989), "International Symposium on Modern Turkish Alphabets" (November 18- 20, 1991), which were attended by scientists from various states and Turkic republics from the former USSR.

In 1997-2005, Nadir Devlet lectured on the Turkic world at the military academies in Istanbul. In 1995-2001, he was the Head of the Department for the Study of the Caucasus and the North Black Sea region at the Turkish Historical Society (Türk Tarih Kurumu).

Significant changes took place in his personal life. In 1998, he divorced his wife. In 2001, he created a new family with Beryl-khanym.

In 2001, he retired from Marmara University, where he had taught and directed the Department of History, had headed the Institute of Social Sciences and the Institute of Turkic Studies. In the same year, Nadir Devlet became the Head of the Department of History of the Faculty of Science and Literature at Yeditepe University (Yedi Tepe Üniversitesi). In 2007, due to a conflict with the management, he resigned from the university. In 2008, he got a job at Istanbul Commerce University (Istanbul Ticaret Üniversitesi) in the Department of International Relations, where he worked for 5 years. From 2014, the scientist began teaching at the Department of International Relations of Istanbul Aydin University (Aydın Üniversitesi), where he finished his teaching career in 2019. The university was too far from Atashehir, where Nadir Devlet lived. While working at Aydin University, the scientist created such fundamental scientific works as: "Turks on the Great Silk Road" (2018)
[Devlet, İpek Yolunda Türkler]; "A Quest for Independence: The Voice of Tatars at Radio Liberty" (2019) [Devlet, A Quest For Independence: Voice of Tatars at Radio Liberty"], "Refugees from Russia: Tatars Spreading across the Distant Diaspora" (2020) [Devlet, Rusya Mültecileri: Uzak Diasporaya Yayılan Tatar].

Before his death, Nadir Devlet wrote weekly articles in the Turkish section of the "Independent" newspaper. At the end of April 2021, the scientist was admitted to a private hospital in Atashehir, where he died of cancer on April 30, 2021.

Professor, Dr. Nadir Devlet was an honorary member of such scientific institutions as: "Turkish Historical Society" (1995-2001),"Mejlis of Tatar Murzas (Jentry)" (1995-2021), the Research Institute of Turkic Studies (1993- 2021), ILESAM (1986-2021), the Academy of Sciences of Tatarstan, to which he was elected in 1993. The scientist also headed the editorial board of a number of journals, such as: "Karadeniz Araştırmaları" ("The Black Sea Studies"), "Stratejik Araştırmalar Dergisi" ("The Journal of Strategic Studies"), "Tatarica", "Tarih ve Medeniyet" ("History and Culture"), "Miras" ("Heritage"), "Central Asian Survey", "Idil-Ural Araştırmaları" ("Studies of Idel-Urals").

Nadir Devlet left us a solid scientific legacy, consisting of 30 books, hundreds of articles and book sections published in Turkey and abroad. At the end of our article, we give the list of the most important works, which gained him immortality:

Devlet, N. (1985). Rusya Türklerinin Millî Mücadele Tarihi (1905-1917) [History of the Russian Turks' National Struggle]. 462 p. Ankara, Türk Kültürünü Araştırma Enstitüsü Yayınları. (In Turkish) ${ }^{3}$

Devlet, N. (1987). Dünyada Türklük Araştırmaları ve Türkiye [Turkic Studies in the World and Turkey]. 134 p. İstanbul, Marmara Üniv. Yay. (In Turkish)

Devlet, N. (1988). Ísmail Bey (Gaspırall). 138 p. Ankara. Kültür ve Turizm Bakanlığı Yayınları. (In Turkish)

Devlet, N. (editor) (1989). Çağdaş Türk Dünyası,[The Modern Turkic World]. 195 p. İstanbul, M. Ü. Fen-Edebiyat Fakültesi Yayınları. (In Turkish)

Devlet, N. (1992). Milletlerarası Çăgdaş Türk Alfabeleri Sempozyumu [The International Symposi-

\footnotetext{
3 Dəylət, N. (1998). Ryssiia tөrkiləreneң milli kөrəsh tarikhy (1905-1907) [History of the National Struggle of the Russian Turks (1905-1907)]. 399 p. Kazan, Milli Kitap.
} 
um on Contemporary Turkic Alphabets]. 72 p. İstanbul, M. Ü. Türkiyat Araştırmaları Enstitüsü Yayınları. (In Turkish)

Devlet, N. (1993) Çă̆daş Türkiler, Doğuştan Günümüze Büyük İslâm Tarihi. [Modern Turks, Great Islamic History from Their Birth to the Present Day]. 607 p. İstanbul, Çağ yayınları. (In Turkish)

Devlet, N. (1997). Idil-Ural Ekspedisyonu: Tatarlar-Başkurtlar-Çuvaşlar, [Idel-Ural Expedition: Tatars-Bashkirs-Chuvash]. 143 p. Ankara, M. Ü. Türkiyat Araştırmaları Enstitüsü Yayınları. (In Turkish)

Devlet, N. (1998). 1917 Ekim İhtilali ve TürkTatar Millet Meclisi (Iç Rusya ve Sibirya Müslüman Türk Tatarlarının Millet Meclisi -1917-1919) [1917 October Revolution and Turkish-Tatar National Assembly (National Assembly of Muslim Turkish Tatars of Inner Russia and Siberia -1917-1919)]. 328 p. İstanbul, Ötüken Yayınları. (In Turkish) ${ }^{4}$

Devlet, N. (1999). Ipek Yolu [The Great Silk Route]. 14 p. Ankara, Türk Tarih Kurumu. (In Turkish)

Devlet, N. (2002). Empires in Eurasia from Chingiz Khan to $20^{\text {th }}$ Century, 106 p. İstanbul, Yeditepe Üniv. Yay. (In English)

Devlet, N. (2005). Studies in the Politics, History and Culture of Turkic Peoples. $425 \mathrm{p}$. İstanbul, Yeditepe Üniv. Yay. (In English)

Devlet, N. (2005). Yıraq könçı̆̆lştağı TatarBaşqortlarğa ni buld $l$ ? [What did Tatar-Baskirs Do in the Far East?]. 99 p. Kazan, Kazan Devlet Üniversitesi Neshr. (In Tatar)

Devlet, N. (2010). Avrasya Fatihi Cengiz Han [Genghis Khan, The Eurasian Conqueror]. 220 p. İstanbul, Başlık Yayın Grubu. (In Turkish)

Devlet, N. (2011) Millet ile Sovyet Arasinda: 1917 Devriminde Rusya Türklerinin Varoluş Mücadelesi [Between the Nation and the Soviets: The Struggle for Existence of the Russian Turks during the 1917 Revolution]. 256 p. İstanbul, Başlık Yayın Grubu. (In Turkish)

Devlet, N. (2011). Ismail Gaspirall: Unutturulan Türkçü, İslâmcı Modernist [Ismail Gaspirali: Forgotten Turkist, Islamist, and Modernist]. 224 p. İstanbul, Başlık Yayın Grubu. (In Turkish)

Devlet, N. (2018). Ipek Yolunda Türkler [Turks on the Great Silk Route]. 224 p. İstanbul, Aydın Üniversitesi iayınları. (In Turkish)

\footnotetext{
${ }^{4}$ Dəүlət N. (2008). 1917 el oktiabr' инкыйлабы вә төрк-татар Милләт Мәжлесе [The October 1917 Revolution and the Turkish-Tatar Millet Majlis]. 382 p. Kazan, Жyen, Milli Kitap.
}

Devlet, N. (2019). A Quest For Independence: The Voice of Tatars at Radio Liberty. 453 p. İstanbul, Aydın Üniversitesi iayınları. (In English)

Devlet, N. (2020). Rusia Mültecileri: Uzak Diasporaia Iayılan Tatarlar [Refugees from Russia: Tatars Spreading across the Distant Diaspora]. 264 p. İstanbul, Aydın Üniversitesi yayınları. (In Turkish)

Devlet, N. (1991). Rus ve soviet silahli kuvvetlerindeki turklerin rolu [The Role of Turks in Russian and Soviet Armed Forces]. X Türk Tarih Kongresi'nden ayribasim. Pp. 811-815. Ankara, Türk Tarih Kurumu Basımevi. (In Turkish)

\section{References}

Devlet, N. (2018). Ipek Yolunda Türkler [Turks on the Great Silk Route]. 224 p. İstanbul, Aydın Üniversitesi iayınları. (In Turkish)

Devlet, N. (2019). A Quest for Independence: The Voice of Tatars at Radio Liberty. 453 p. İstanbul, Aydın Üniversitesi iayınları. (In English)

Devlet, N. (2020). Rusia Mültecileri: Uzak Diasporaia Iayllan Tatarlar [Refugees from Russia: Tatars Spreading across the Distant Diaspora]. $264 \mathrm{p}$. İstanbul, Aydın Üniversitesi iayınları. (In Turkish)

Devlet, G. Beril. (2014). Bir Ömre Altı Hayat Siğdıran Nadir Devlet'in Iaşam Öyküsü, [A Life-Story of Nadir Devlet that Fits Six Lives into a Lifetime]. 384 p. İstanbul, Çatı Kitapları. (In Turkish)

İsmail Türkoğlu (editor) (2005). Rokiie Deületkildi: Bir Tatar Hatınının açı yazmışı, [Rokiye Deületkildi: The Bitter Life-Story of a Tatar Woman]. 110 p. Kazan, Kazan University. (In Tatar) 


\title{
НАДИР ДАУЛЕТ (1944-2021): ПАМЯТИ УЧЕНОГО, УЧИТЕЛЯ, ДРУГА
}

\author{
Исмаил Тюркоглу, \\ Университет искусств Мимара Синана, \\ Турция, 34427, г. Стамбул, Фындыклы, \\ turkogluismail@yahoo.de.
}

Надир Даулет родился 15 июля 1944 года в городе Мукден, который в настоящее время является столицей провинции Ляонин Китайской Народной Республики и называется Шэньян. Будущий ученый родился в татарской семье Ибрагима и Рукии Девлеткильдиевых. Его прадед - Мухаммеджан эфенди - был купцом и промышленником. В Петропавловске (ныне Казахстан) семья Девлеткильдиевых владела маслобойней, мыловаренным производством, а также мельницами и керосиновыми складами. Мечеть, построенная семьей в этом городе в 1868 году, по-прежнему открыта для прихожан. Представители рода, насчитывающего 38 семей, среди которых были татарские князья и потомки ханов Золотой Орды, до 1917 года проживали в России. После революции, растеряв имущество, утратив титулы и социальный статус, они были вынуждены поселиться в различных уголках Союза Советских Социалистических Республик. Трагическая история скитаний семьи Девлеткильдиевых в эпоху Сталина была реконструирована в шестисерийном документальном фильме «История моей семьи» (реж. Марина Разбежкина).

Рукия ханум была дочерью купца Сабиржана Мухаммедиш(ин)а (1873-1947) ${ }^{1}$. Дед будущего ученого занимался торговлей вдоль строящейся Транссибирской железной дороги. Добытое в Сибири сырье и купленные здесь предметы домашнего обихода Сабиржан абзый продавал в различных городах Сибири, на станциях Транссиба и в европейской части России.

Мать Надира Даулета Рукия ханум (19081989) родилась в 1908 году в селе Утямышево (Үтәмеш) Тетюшского уезда Казанской губернии (ныне - Апастовский район Республики

\footnotetext{
${ }^{1}$ См. подр. биографию Рукии Даулет-Килде в книге «Рокыя Дәүләт-Килде: Бер татар хатының ачы язмышы» [Рокыя Дәүләт-Килде: Бер татар хатының ачы язмышы]
}

Татарстан). Из-за коммерческой деятельности своего отца она с раннего возраста была вынуждена совершать дальние путешествия. В 1911 году семья переехала в сибирский город Иркутск, в 1916 году перебралась оттуда в Хабаровск. На два года они обосновались в городе Благовещенске, а в 1918 году семья снова вернулась в Хабаровск. Поскольку отец Рукии имел хорошие доходы, он отправил ее учиться в русскую гимназию города Уссурийска, которую она закончила в 1919 году. В 1925 году изза социальных потрясений в России семья вынуждена была переехать в Китай и поселиться в Харбине, а в 1927 году перебраться в Японию и начать жить в Токио. Семья селилась в городах, где жили семьи татарских эмигрантов, уехавших из России до и после революции 1917 года. Рукия ханум в Токио посещала курсы английского языка и секретарей, затем до 1935 года преподавала в Исламской школе, где учились дети татарских эмигрантов, проживающих в городе. Известный татарский писатель Гаяз Исхаки, живший в изгнании в Берлине, Варшаве, наладивший выпуск журнала «Яңа милли юл» («Новый путь развития нации»), нуждался в постоянной финансовой поддержке, чтобы вести свою активную деятельность. Так как число тюрко-татарских мухаджиров в Европе было небольшим, они не могли оказывать ему достойную экономическую помощь. В 1933-1938 гг. в поисках финансирования Г. Исхаки отправился на Дальний Восток. Добравшись до Токио, волей судьбы он познакомился с Рукией ханум. Воспитанная на произведениях писателя, под впечатлением от его речей, мать Надира примкнула к числу соратников, борцов за освобождение Идель-Урала.

Лидеры татарской исламской общины в Токио, состоящей из зажиточных семей, Мухаммад Курбангали(ев) и (Г)Абдуррешид Ибрагим(ов) не позволили Гаязу Исхаки установить над ней контроль. Стоит отметить, что у последнего с Абдуррашидом Ибрагим(ов)ым 
сложились напряженные отношения намного раньше, начиная с 1905 года. Гаяз Исхаки в молодости был социалистом и вел светский образ жизни, поэтому ему трудно было найти общий язык со старшим поколением, строго придерживающимся исламских традиций. Это привело к серьезным разногласиям. После этого Гаяз Исхаки 4-14 февраля 1935 года решил организовать Дальневосточный съезд тюрко-татар в Мукдене (Маньчжурия). В лице отца Рукииханум он обрел своего сторонника. Вскоре мать Надира Давлета, благодаря знанию иностранных языков, стала для Гаяза Исхаки незаменимым помощником. По итогам работы Съезда курултая в этом городе начала выпускаться с 1 ноября 1935 года газета «Милли байрак» («Национальный флаг»), а Гаяз Исхаки вернулся назад в Европу. В письмах к Гаязу Исхаки Рукия ханум умоляла его забрать ее в Европу, но он игнорировал ее просьбы, считая, что она должна принести себя в жертву нации. Последующие события свидетельствуют о том, что Рукия ханум так и поступила: аудитория «Милли байрак» насчитывала 300-400 подписчиков, написанная от руки газета тиражировалась с помощью типографского камня, вся нагрузка по выпуску газеты легла на плечи женщины.

17 октября 1943 года она вышла замуж за Ибрагима Девлет-Кильди, который был главным редактором газеты «Милли байрак». 15 июля 1944 года у них родился сын, которого нарекли именем Надир. 10 августа 1945 года войска Советского Союза вошли в Маньчжурию. Офис газеты «Милли Байрак» был опечатан одним из первых. Родителей Надира арестовали, беременную Рукию ханум с мужем вскоре доставили в Читу. Сабиржан эфенди остался с годовалым внуком на руках. Во время допросов и пыток супруги были вынуждены признать выдвигаемые против них обвинения. Спустя год после ареста, после десятиминутного суда они были приговорены по ст. 58 (п. 2. и п. 11) Уголовного кодекса РФ к лишению свободы на срок десять лет с конфискацией имущества и отбыванием в трудовом лагере (ГУЛАГ). В тюрьме Рукия ханум 22 апреля 1946 года родила дочь Фариду. Вместе с новорожденной ее отправили из Читы в трудовой лагерь в Караганде, в один из крупных шахтерских городов Казахстана. Когда девочке исполнилось три с половиной года, ее забрали у матери и отдали на воспитание в государственный детский дом для детей «врагов народа», где с юных лет воспитывали ненависть к родителям.
Тяжелые условия труда на кирпичном заводе и в каменном карьере, которые были не по плечу даже мужчинам, сильно подорвали здоровье Рукии ханум. Смерть Сталина не принесла жизни узников облегчения, мать Надира Даулета стала угасать на глазах.

В феврале 1955 года из-за прогрессирующих хронических заболеваний и невозможности трудиться в условиях карагандинского лагеря ее перевели в трудовой лагерь, что находился в Мордовии, где она начала работать в мастерской по пошиву военной одежды. Спустя год, 10 ноября 1955 года, по истечении срока наказания, ее отправили в Новосибирскую тюрьму, затем - на поселение к мужу, в деревню Вдовино, что на севере Новосибирской области, где он отбывал ссылку. Здесь располагалась государственная птицефабрика. После длительной разлуки супруги наконец воссоединились. В октябре 1956 года им удалось вернуть из детдома дочь, где она провела 7 лет. Условия проживания в деревне были не из легких. Рукия ханум провела 10 лет трудовом лагере, 6 лет в ссылке в Новосибирской области. В 1961 году они дождались послабления: семье разрешили вернуться на родину мужа - в Петропавловск (Кызыльяр). Бывшим «врагам народа» было трудно найти работу. После долгих мытарств Рукия ханум в 1962 году с трудом удалось найти работу по специальности: она начала преподавать английский язык. Однако беды продолжали преследовать семью. 21 апреля 1967 года от сердечной недостаточности скончался глава семьи - Ибрагим бей. Рукия ханум преподавала до 1976 года, так как ее крошечной пенсии, получаемой с 1972 года, не хватало на жизнь. Она тяжело переживала разлуку с дочерью, которая работала инженером на военном оптико-механическом заводе (КОМЗ) в Казани. После длительной переписки 30 сентября 1982 года ей удалось получить разрешение переехать в Казань. Они с дочерью жили в коммунальной квартире, однако власти ей отказали в прописке. Спустя годы профессор Надир Даулет, благодаря покровительству друзей в Казани, улучшил жилищные условия матери: она получила однокомнатную квартиру.

Встреча матери и сына состоялась в июле 1977 года в Мюнхене. Надир-бей успел к тому времени создать семью и стать отцом. Гирею на момент встречи с бабушкой исполнилось четыре года. Вторая встреча матери и сына состоялась в Мюнхене в 1983 году. Рукия ханум удалось взять на руки второго внука по имени 
Юлай. Это была последняя встреча матери с сыном и его семьей. Ее жизнь, полная приключений и бед, оборвалась в Казани в 1989 году, когда ей исполнился 81 год. Гаяз Исхаки, действительно, принес ее в жертву татарскому народу.

Отец Надира Даулета - Ибрагим бей - родился 27 февраля 1901 года в городе Петропавловске (Кызыльяр). В семье было 11 детей. Первичное образование Ибрагим бей получил в медресе, построенном его дедом. Затем он продолжил образование в русской средней школе, которую закончил в 1918 году. Спасаясь от революционного пожара, полыхавшего в России, Ибрагим бей отправился во Владивосток, расположившийся на побережье Японского моря. Здесь он поступил учиться на курсы радиотелеграфистов. Хотя Ибрагим бей был записан моряком в армию адмирала Колчака, который сражался против красных, вскоре его принудительно записали в качестве лейтенанта в армию барона Романа Унгерна фон Штернберга, который был в рядах белых. Через некоторое время он по приглашению своих соотечественников отправился провести отпуск в Харбине. Ибрагим бей помимо своей воли был втянут в войну, когда в регион нагрянули красные. За то, что Ибрагим бей заснул на посту, барон Роман Унгерн фон Штернберг приговорил его к смертной казни. Отец Надира выжил благодаря помощи татарского офицера, который укрыл его в своей семье, проживающей в Харбине. В 19201922 гг. Ибрагим бей учился в украинском лицее, после окончания которого, мечтая заняться торговлей, уехал в Токио. Ему не удалось здесь пустить корни из-за страшного землетрясения 1923 года и его трагических последствий. В 1925 году он решил попробовать удачу в Мукдене (ныне - Шиньян). Здесь он встретился с Разией ханум. У них родились две дочери. Ибрагим бей был делегатом Мукденского съезда (Курултая) во главе с Гаязом Исхаки. Здесь он познакомился с Рукией ханум, и они начали вместе выпускать газету «Милли байрак». Ибрагим бей был главным редактором и ключевым автором газеты. В 1937 году он развелся с женой. Спустя шесть лет, в 1943 году, Ибрагим бей женился на Рукие ханум.

После ареста из Читы его отправили в знаменитую московскую тюрьму Лефортово для проведения дальнейшего расследования. Вскоpe после недолгого судебного разбирательства его приговорили по ст. 58 (п. 10. и п. 11) Уголовного кодекса РФ к лишению свободы на срок десять лет с отбыванием в трудовом лагеpe (ГУЛАГ). Было принято решение о конфискации его имущества, и он был отправлен в лагерь в город Углич (Ярославская область), к северу от Москвы. Вскоре из-за тяжелых условий труда он заболел и полгода провел в лагерной больнице. После выздоровления его перевели в лагерь номер № 11 в Мордовии, где зимой приходилось валить лес в тридцатиградусный мороз. По истечении срока наказания 20 апреля 1955 года его отправили в ссылку в Новосибирскую область. В совхозе Вдовино он пас скот, работал чернорабочим на ферме, трудился в поле. Вернувшись с семьей в родной город, работал на складе. Семья получила свое первое жилье в 1964 году, однако их радость была недолгой. Жизнь главы семьи оказалась короткой. Свыше было предопределено, что отцу так и не довелось встретиться с сыном.

Трагично сложилась и судьба деда Надира Даулета. Он скончался от столбняка из-за ржавого гвоздя, повредившего ему глаз. Никто не знает, кто полгода заботился о маленьком мальчике.

Приемные родители сыграли огромную роль в жизни Надира Даулета и его становлении как ученого. Когда судьбе было угодно соединить судьбу осиротевшего мальчика с Axтем беем и Айнирджамалой ханум, супруги планировали эмигрировать из Китая в Турцию. Благодаря помощи еврейского торговца, они вначале вывезли ребенка известных родителей из Мукдена в Пекин, где усыновили, затем семья отправилась в Шанхай. После окончания Второй мировой войны, в 1949 году, власть в Китае оказалась в руках коммунистов. В жизни Надира появилась неродная сестра по имени Рашида. Благодаря помощи друзей, работавших в турецком посольстве, она получила турецкую визу. 18 января 1949 года семья выехала из Шанхая в Стамбул. После семидесятидневного тяжелого круиза на корабле, 31 марта 1949 года они прибыли в Стамбул. Приемные родители в Турции сменили фамилию и взяли фамилию Даулет, чтобы в дальнейшем родные родители смогли разыскать ребенка. Проведя ночь в отеле в Сиркеджи, благодаря Гаязу Исхаки, они поселились в квартире в квартале Чершембе района Фатих. Семья оказалась в трудном экономическом положении, пока неродная сестра Надира не сумела устроиться благодаря помощи Рашида Хамдуллы Супхи Танрыовера секретарем в нефтяную компанию. Семья поселилась в подвале жилого дома в Шишли. 19 мая в 1951 года Надир 
поступил учиться в местную начальную школу, которую закончил в 1956 году. Благодаря активному участию в судьбе мальчика состоятельного Ахмеда Вели Менгера (уроженца Большого Менгера в Заказанье), близко знавшего родителей мальчика в период их работы в редакции «Милли Байрак», и Кемаля Лукмана, этнического татарина, который был первым инженеромнефтяником Турции, Надир Даулет продолжил обучение на среднем отделении немецкого частного лицея (Özel Alman Lisesi). Именно в этот период Надир узнал, что воспитывается в семье приемных родителей, что повергло его на короткое время в депрессию. Надир Даулет не смог закончить высшее отделение этого учебного заведения, так как Ахмеду Вели Менгеру не удалось добиться усыновления мальчика и он прекратил финансирование его обучения. Кемаль Лукман не вмешался в ситуацию, так как не хотел ссориться с самым богатым татарином в Турции. Из-за этого в 1962 году Надиру Даулету пришлось продолжить обучение в вечерней школе в Вефи (Vefa Akşam Lisesi). Учебу он совмещал с работой. Надир Даулет, благодаря помощи эмигрантов, наладил переписку со своей родной матерью и сестрой Фаридой.

В 1967-1971 гг. Надир Даулет учился на историческом отделении факультета литературы Стамбульского университета. В 1969 году он женился на Дилек Оракоглу, от брака с которой у него родилось два сына: Гирей и Юлай.

Точкой отсчета его трудовой биографии стал 1951 год. Ему пришлось трудиться на разных работах. Отец его одноклассника по средней школе - профессор доктор Рашид Рахмети Арат - в 1963 году устроил несовершеннолетнего Надира корректором в «Исламскую энциклопедию» (İslâm Ansiklopedisi'), издаваемую Министерством образования. Вместе с друзьями Надир Даулет приступил к изданию «Бюллетеня Тукая» (Tukay Bülteni). В 1967 году он получил приглашение на работу от Научно-исследовательского института тюркской культуры (Türk Kültürü Araştırma Enstitüsü), штаб-квартира которого находилась в Анкаре. Надир Даулет начал трудиться уполномоченным по составлению словаря в Стамбульском офисе (1967-1972). Институт в это время возглавлял его соотечественник - профессор, доктор Ахмет Темир. В эти годы Надир Даулет возглавил Общество культуры и помощи казанским тюркам. Вместе с друзьями он издавал журнал «Казань».

Благодаря протекции своего друга Ферита Аги, Надир Даулет работал в татаро-башкирской редакции Радио «Азатлык», созданной США после Второй мировой войны в Мюнхене для этнической аудитории, проживающей в Союзе Coветских Социалистических Республик (RFE/RL Inc. - радио «Свободная Европа / Радио Свобода Inc.). Благодаря этой работе, в 1972 году Надир Даулет переехал с семьей в Мюнхен. В 19721975 гг. он был ведущим радиопрограмм, благодаря чему усовершенствовал свое владение немецким, английским, татарским языками, получил доступ к разным ресурсам. Именно в этот период Надир Даулет овладел татарским литературным языком. В апреле 1975 года из-за необходимости отслужить в армии он был вынужден вернуться в Турцию. Его военная служба проходила в Борнове, провинции Измир, в 58-учебной дивизии, 57-й Артиллерийской учебной бригаде. После службы в армии он некоторое время работал в холдинге Ахмеда Вели Менгера в Стамбуле, но, не видя здесь будущего, он снова вернулся в Мюнхен, где продолжил свою работу на радио.

В 1976 году под руководством профессора, доктора Ибрагима Кафесоглу он начал работать над докторской диссертацией «История национальной борьбы русских тюрок (1905-1917)» («Rusya Türkleri’nin Milli Mücadele Tarihi (19051917)»), которую защитил в 1982 году. Надир Даулет стал подавать заявки в разные вузы, чтобы всецело посвятить себя научной и преподавательской работе.

По приглашению декана факультета науки и литературы Университета Мармара профессора, доктора Хакки Йолдыза осенью 1984 года Надир бей вернулся в Стамбул и начал преподавать на историческом отделении. После возвращения на родину он продолжил работу на радио: вплоть до 2020 года вел еженедельную передачу «Новости Турции» под псевдонимом Ахтем Ибрагимов.

После распада Советского Союза авторитет Надира Даулета в обществе сильно укрепился, так как политики относились к нему, повидавшему мир, с большим уважением. Президент Тургут Озал и премьер-министр Месут Йылмаз попросили его разработать предложения о тюркоязычных народах, живущих в Советском Союзе. Циклы статей ученого были опубликованы в различных журналах. Увидел свет его фундаментальный труд «Современные тюрки» («С̧ağdaş Türkiler»), который не потерял своей актуальности и поныне. 
Преподавательская карьера ученого также пошла в рост²: в 1986 году он стал деканом, в 1992 году - профессором. С июня 1989 по июнь 1990 года он работал приглашенным исследователем в Центре центральноазиатских исследований Колумбийского университета, где получал ежегодную стипендию, присуждаемую Американским советом научных обществ и совместной программой по развитию советских исследований Совета по исследованиям в области социальных наук. Надир Даулет работал в качестве приглашенного преподавателя в осенний семестр на кафедре истории Университета Висконсина / Мэдисона в Соединенных Штатах (август 1996 январь 1997 года). Здесь он преподавал курс «Вторжения и империи: Средняя Азия от Чингисхана до Сталина, революция в Средней Азии и реформа в Исламе» («İşgaller ve İmparatorluklar: Cengiz Han'dan Stalin'e Orta Asya ve İslâm ve Orta Asya'da İhtilal ve Reform»). До 1991 года Надир Даулет был заместителем директора Центра исследований и практических занятий Турции, основанного в 1986 году в Университете Мармара. Благодаря политике гласности президента СССР М. С. Горбачева, ученому в 1990 году удалось приехать в Казань на научный форум. Во время этого визита ему удалось свидеться со своей сестрой Фаридой, которую он знал только по переписке. Они встретились на вокзале спустя сорок пять лет разлуки. Надир Даулет улучшил ее материальное положение в России, регулярно оказывая ей финансовую помощь до самой ее смерти.

Благодаря совместным усилиям ректора Университета Мармара, профессора, доктора Орхан Огуза, декана факультета науки и литературы, профессора, доктора Хакки Дорсын Йолдыза, профессора, доктора Инжи Енгинюн и профессора, доктора Надире Даулета, 24 января 1991 года парламент принял закон о создании Научно-исследовательского института тюркологических исследований (Türkiyat Araştırma Enstitüsü) при Университете Мармара. В 19911997 гг. Надир Даулет занимал в этом институте должность заместителя директора. Параллельно он преподавал на отделении истории факультета науки и литературы. В 1997 году, после выхода на пенсию профессора, доктора Инжи Енгинюн Надир, Даулет занял пост директора института. Под его руководством был организован ряд крупных международных научных мероприятий: «Симпозиум по исследованиям Тюркизма и Тур-

\footnotetext{
${ }^{2}$ См. подр. сведения о этом периоде жизни ученого: Devlet G. Beril [Devlet G. Beril]
}

ции в мире» (18-20 октября 1986 года); «V Международный конгресс по социальной и экономической истории Турции» (21-25 августа 1989 года), «Международный симпозиум по современным турецким алфавитам» (18-20 ноября 1991 года), в которых приняли участие ученые различных тюркских республик из бывшего СССР.

В 1997-2005 гг. Надир Даулет читал лекции по тюркскому миру в военных академиях в Стамбуле. В 1995-2001 гг. он занимал должность заведующего отделом по изучению Кавказа и Северочерноморского региона в Турецком историческом обществе.

Значительные перемены произошли и в его личной жизни. В 1998 году он развелся с женой, а в 2001 году создал новую семью с Берил ханум.

В 2001 году ученый ушел в отставку в Университете Мармара, где преподавал и руководил кафедрой истории, возглавлял Институт социальных наук и Институт тюркологических исследований. В том же году в Университете Едитепе (Yedi Tepe Üniversitesi) Надир Даулет возглавил кафедру истории факультета науки и литературы, однако в 2007 году из-за конфликта с руководством он уволился из вуза. В 2008 году он устроился на работу в Стамбульский коммерческий университет (İstanbul Ticaret Üniversitesi) на отделение международных отношений, где проработал 5 лет. С 2014 года ученый начал преподавать на кафедре международных отношений, где завершил свою преподавательскую карьеру в 2019 году: университет был слишком далеко от Аташехира, где жил Надир Даулет. Во время работы в университете ученый создал такие фундаментальные научные работы, как «Тюрки на Великом шелковом пути» (2018) [Devlet, İpek Yolunda Türkler], «Стремление к независимости: Голос татар на „Радио Свобода“» (2019) [Devlet, A Quest For Independence: Voice of Tatars at Radio Liberty], «Беженцы из России: татары, распространяющиеся по далекой диаспоре» (2020) [Devlet, Rusya Mültecileri: Uzak Diasporaya Yayılan Tatarlar].

До своей смерти Надир Даулет писал еженедельные статьи в турецкий раздел газеты Independet («Индепендент»). В конце апреля 2021 года ученый был госпитализирован в частную больницу в Аташехире, где 30 апреля 2021 года скончался от онкологического заболевания.

Профессор, доктор Надир Даулет был почетным членом таких научных учреждений, как «Турецкое историческое общество» (1995-2001), 
«Меджлис татарских мурз» (1995-2021), Научноисследовательский институт тюркологических исследований (1993-2021), İLESAM (1986-2021), Академия наук Татарстана, в которую он был избран в 1993 году. Ученый также возглавлял редакционные коллегии ряда журналов, таких как «Karadeniz Araștırmaları» («Черноморские исследования»), «Stratejik Araştırmalar Dergisi» («Журнал стратегических исследований»), «Tatarica» («Татарика»), «Tarih ve Medeniyet» («История и культура»), «Miras» («Наследие»), «Central Asian Survey» («Обзор Центральной Азии»), «İdil-Ual Araştırmaları» («Иследования Идель-Урала»).

Надир Даулет оставил потомкам солидное научное наследие, состоящее из 30 самостоятельных изданий, сотен статей и книжных разделов, опубликованных в Турции и за ее пределами. В конце нашей статьи мы приводим наиболее важные из них, благодаря которым он обрел бессмертие:

Дәүләт Надир. Ерак Көнчыгыштагы татарбашкортларга ни булды. Казан: Казан дәүләт ун-ты, 2005. 99 б.

Devlet N. Rusya Türklerinin Millî Mücadele Tarihi (1905-1917) Ankara: Türk Kültürünü Araştırma Enstitüsü Yayınları? 1985. 462 s. $^{3}$

Devlet N. Dünyada Türklük Araștırmaları ve Türkiye. İstanbul: Marmara Üniv. Yay, 1987. $134 \mathrm{~s}$.

Devlet N. İsmail Bey (Gaspıral1). Ankara: Kültür ve Turizm Bakanlığı Yayınları, 1988. 138 s.

Çağdaş Türk Dünyası / Devlet N. editor. İstanbul: M.Ü. Fen-Edebiyat Fakültesi Yayınları, 1989. $195 \mathrm{~s}$.

Devlet N. Milletlerarası Çağdaş Türk Alfabeleri Sempozyumu. İstanbul: M.Ü. Türkiyat Araştırmaları Enstitüsü Yayınları, 1992. $72 \mathrm{~s}$.

Devlet N. Çağdaş Türkiler, Doğuştan Günümüze Büyük İslâm Tarihi. İstanbul: Çağ yayınlar1, 1993. $607 \mathrm{~s}$.

Devlet N.. İdil-Ural Ekspedisyonu: TatarlarBaşkurtlar-Çuvaşlar Ankara: M.Ü. Türkiyat Araştırmaları Enstitüsü Yayınları, 1997. 143 s.

Devlet N. 1917 Ekim İhtilali ve Türk-Tatar Millet Meclisi (İç Rusya ve Sibirya Müslüman Türk Tatarlarının Millet Meclisi -1917-1919). İstanbul: Ötüken Yayınları, 1998. $328 \mathrm{~s}^{4}$

\footnotetext{
3 Дәуләт Н. Руссия төркиләренең милли көрәш тарихы (1905-1907). Казан: Милли китап, 1998. 3996.

${ }^{4}$ Дәуләт Н. 1917 ел октябрь инкыйлабы вә төрктатар Милләт Мәжлесе. Казан: Жыен, Милли китап, 2008. 382 б.
}

Devlet N. İpek Yolu. Ankara: Türk Tarih Kurumu, 1999. $14 \mathrm{~s}$.

Devlet N. Empires in Eurasia from Chingiz Khan to 20th Century. İstanbul: Yeditepe Üniv. Yay, 2002. $106 \mathrm{p}$.

Devlet N. Studies in the Politics, History and Culture of Turkic Peoples. İstanbul: Yeditepe Üniv. Yay, 2005. 425 p.

Devlet N. Avrasya Fatihi Cengiz Han. İstanbul: Başlık Yayın Grubu, 2010. 220 s.

Devlet N. Millet ile Sovyet Arasinda: 1917 Devriminde Rusya Türklerinin Varoluş Mücadelesi, İstanbul: Başlık Yayın Grubu, 2011. $256 \mathrm{~s}$.

Devlet N. İsmail Gaspiralı: Unutturulan Türkçü, İslâmcı Modernist. İstanbul: Başlık Yayın Grubu, 2011. 224 s.

Devlet N. İpek Yolunda Türkler. İstanbul: Aydın Üniversitesi yayınları, 2018. 224 s.

Devlet N. A Quest For Independence: Voice of Tatars at Radio Liberty. İstanbul: Aydın Üniversitesi yayınları, 2019. $453 \mathrm{~s}$.

Devlet N. Rusya Mültecileri: Uzak Diasporaya Yayılan Tatarlar. İstanbul: Aydın Üniversitesi yayınlar1, 2020. $264 \mathrm{~s}$.

Devlet N. Rus ve soviet silahli kuvvetlerindeki turklerin rolu // X Türk Tarih Kongresi'nden ayrıbasım. - Ankara: Türk Tarih Kurumu Basımevi, 1991. S. 811-815.

\section{Литература}

Рокыя Дәүләт-Килде: Бер татар хатының ачы язмышы / Исмаил Төрекоглы ред. Казан: Казан унты нәшр. Kazan, 2005. 110 б.

Devlet G. Beril. Bir Ömre Altı Hayat Siğdıran Nadir Devlet'in Yaşam Öyküsü. İstanbul: Çatı Kitapları. 2014. $384 \mathrm{~s}$.

Devlet N. İpek Yolunda Türkler. İstanbul: Aydın Üniversitesi yayınları, 2018. $224 \mathrm{~s}$.

Devlet N. A Quest For Independence: Voice of Tatars at Radio Liberty. İstanbul: Aydın Üniversitesi yayınları, 2019. $453 \mathrm{~s}$.

Devlet $N$. Rusya Mültecileri: Uzak Diasporaya Yayılan Tatarlar. İstanbul: Aydın Üniversitesi yayınları, 2020. $264 \mathrm{~s}$. 